\title{
From the Frontline
}

\section{'Blood Money': A NZ investigative journalism case study}

\begin{abstract}
Metro, the leading New Zealand glossy magazine reporting issues and society, published an investigative article 'BLOOD MONEY' probing the NZ Superannuation Fund (NZSF) investment in the controversial US-owned Freeport copper and gold mine at Grasberg as its lead feature in the December 2011 edition. Prior to this publication, the two Indonesianruled Melanesian provinces comprising West Papua on the island of New Guinea had remained largely ignored by New Zealand mainstream media for four decades. ${ }^{1}$ The mine has been at the centre of human rights and environmental abuse allegations for most of this period. In her investigation, the author sought to establish how the NZSF laid claim to being a 'responsible investor' while remaining involved in a mine with a long history of being implicated in alleged human rights violations and severe environmental damage. This exegesis considers the author's reportage and methodology and how she included peace journalism concepts in the research and publication of 'Blood Money'. It also analyses the public response.
\end{abstract}

Keywords: censorship, environmental journalism, human rights, investigative journalism, investment, peace journalism

KAREN ABPLANALP

Pacific Media Centre

TOURNALISTS and humanitarian organisations are banned from visiting the Indonesian-ruled region of West Papua (Chesterfield, 2011, p. 32). According to a Pacific Journalism Review media freedom report in 2011 (Perrottet \& Robie, p.155), in one year there had been 'two killings of journalists, five abductions or attempted abductions, 18 assaults (includ- 
ing repeated cases against some journalists), censorship by both the civil and military authorities and two police arrests (but no charges)'.

The Auckland-based Indonesia Human Rights Committee has actively raised awareness about Indonesia human rights abuses in West Papua (see www.indonesianhumanrights.org.nz) but there has been limited coverage of these issues in the New Zealand media. In this case, mainstream media had largely ignored West Papua, apart from specialised new services such as Pacific Scoop (pacific.scoop.co.nz) and the Pacific Media Centre (pmc.aut. ac.nz), which continued to cover the region.

As the 'BLOOD MONEY' investigation began in October 2011, the miners at Grasberg initiated a three-month long strike, involving more than 8000 of the mines workforce, ending one month after the author's article went to press (Workers may return, The Jakarta Post, 3 January 2012).

In order to gain sources from within the region, which is 'blacked out' to the media (Perrottet \& Robie, 2011b), the author contacted PT Freeport union spokespeople for the striking miners. Following developments in the miners' strike and other West Papuan stories in the Indonesian press also led to excellent sources on the ground.

'Blood Money' was researched and written while the author undertook studies on an Asia-Pacific Journalism postgraduate paper at the Auckland University of Technology in the second semester 2011. The Pacific Media Centre provided essential links to West Papuan networks and a strong research base. Bacon (2011) considers that investigative journalists working within academia can play an important role in filling a gap that traditional journalism lacks and a space that public relations journalism crowds.

Metro magazine editor Simon Wilson saw the value in publishing 'Blood Money' immediately and appreciated the fact that the story was researched and produced at a university. 'Blood Money' was a good collaboration between the author and Metro. It was clear to me that the author was able to reach the high standard of research required for investigative journalism, in part due to the academic demands of her course work' (Wilson, 2012).

The author chose to approach the research and production of 'Blood money' incorporating notions of peace journalism (Aslam, 2011; Galtung, 2003; Hackett, 2011; and Robie, 2011). Aslam (2011) suggests a journalist's own attitudes and approach towards a conflict is crucial to how that issue is eventually framed. Rather than keeping these attitudes separate, she argues 
that a journalist stay 'close' to a story instead of aiming to be 'impartial'. She also suggests the importance of a reflexive practice on the part of the journalist. Dixit (2011) also considers that a journalist's internal process and influence has a role to play in producing peace journalism. A critic of the definition of peace journalism, Hanitzch (2007), argues this approach is just another name for traditional, high quality journalism and they are essentially the same thing. It may be that the journalist's personal commitment that Aslam (2011) and Dixit (2011) refer to is a differential between good quality journalism and peace journalism.

Aslam (2011) also argues that the attitude of the journalist towards a story frames it and that the media can choose to act in such a way that enables or fosters peace or conflict by the way an issue is contextualised and constructed. Dixit (2011) discusses the importance of the journalist's internal process and influence on a story, asking the reporter to examine their reasons for writing a story: will the story add to conflict or assist in a deeper understanding of the problems? In the case of 'Blood Money' the author did have the intention of assisting in providing a deeper public understanding of not only the issues at stake with the mine, but also the wider issues at stake in West Papua. The author was sincerely perplexed about how the position of responsible investing could be taken alongside the Grasberg mining operation.

A summarised selection of public responses to 'Blood Money' is provided at the conclusion of this exegesis in the form of letters to the editor to give a sense of what possible new understandings were reached.

The author communicated with union officials of the striking miners, and remained close to the miners' story as it unfolded. The author was alerted to the possible danger for the miners ahead of the deaths and contacted her sources and Indonesian media outlets as the danger increased. These media outlets were also concerned for miner safety. The subsequent deaths of striking miners proved to be a turning point in the author's approach to the story. It could have been at that point that the piece turned into advocacy journalism, but the decision was made to use a peace journalism framework.

One task of the peace journalist, according to Galtung (2003), is that the journalist aims to uncover the facts from all sides rather than revealing the truth from one side. In the case of 'Blood Money' the task of 'revealing the truth' proved to be a time-consuming and laborious exercise involving the translation, cross-checking and understanding of public relations documents 
that made up a lot of the NZSF responses. Material from the miners union was also difficult to verify.

Galtung (2003) talked about the importance of giving a historical perspective to a conflict and of focussing on the peacemakers in a story. The author interviewed Budi Hernawan, a Franciscan friar who worked in West Papua, who was an invaluable source on the ground and also a 'peacemaker'. In some ways, the NZSF saw themselves as 'peacemakers', arguing by retaining an interest in the mine, they were in fact adopting a kind of 'watchdog' role. The 'watchdog' claims did not stand up to scrutiny by the author, and despite this information being passed back to the NZSF, the fund management's position remained unchanged. It could be argued that the story was stronger by leaving this discrepancy to speak for itself rather than the author being seen to be critiquing the NZSF in some way. This was true of all of the points the NZSF made which did not stand up to scrutiny. The author saw the Auckland-based Indonesia Human Rights Committee and Amnesty International as peacemakers who had valuable experience working on peace issues and West Papua. In the case of the Green Party, even though this is a political party, it also has had considerable experience working with the NZSF on matters seen internationally as issues of peace - such as the effects of environmental degradation and its effects on a community as raised in the article.

'Blood Money' (Abplanalp, 2011) prompted 'lots of feedback', according to Metro magazine (Upfront-Yours etc, Metro January-February, 2012,). Even though 'Blood Money' did not advise a course of action, the majority of readers concluded that NZSF should divest from the mine. Letters of support were also received from Amnesty International, the Indonesia Human Rights Committee and the New Zealand Green Party. Dr Mills (2012), who has had firsthand experience of the effects of mining on the health of a population, wrote:

'Blood Money' raises critically important issues about how our money is being invested through the NZ Super Fund. The indigenous population of West Papua continues to oppose Indonesian occupation, despite being subject to gross violations of human rights for decades. (Mills, p. 20)

She said that in 2010 she had seen first hand the impact of poor employment practices and environmental degradation on local communities just across the border in Western Province, Papua New Guinea, while responding to an outbreak of cholera (the first ever documented in the region). 
In the majestic Fly River, huge volumes of highly toxic mining tailings have been dumped for years. It is estimated it will take at least 300 years for the river to return to any 'normal' state.

Also, international forestry companies are stripping the hinterland of hardwood forest. People living in the river communities' benefit minimally and suffer serious ill health effects from mining pollution. There is little clean water, totally inadequate sanitation and minimal health services, all of which contributed to the cholera outbreak. One can only be somewhat skeptical about the 'responsible investment' position of NZSF. As responsible Pacific neighbours, we must urge the NZSF to urgently disinvest (p. 20).

Rather than just calling for the NZSF to divest, a public group chose to divest their own money from Rio Tinto, the other main owner of the Grasberg mine. The president of the Methodist Church of New Zealand, Rev John Roberts, wrote to Metro magazine in January 2012, saying:

I read with interest Karen Abplanalp's article on the Grasberg mine in West Papua published in the December issue of Metro. Because of concerns about the Grasberg mining operation, several of us in the Methodist Church lobbied the Investment Advisory Board (IAB) of the Methodist Church, in an effort to get the MTA to divest itself of shares in Rio Tinto. The IAB was provided with material expressing concern about the Grasberg mining operation. As a result of this, the church's IAB in December 2011 decided investment in Rio Tinto was no longer considered appropriate for church funds.

Groups within the church were also requested by the church to divest from the mine.

The MTA and another substantial trust in the life of the church relinquished their holdings in Rio Tinto in the same month and all groups within the life of the church who may have share holdings in Rio Tinto were advised of this decision and requested to divest themselves of their investments in Rio Tinto. (J. Roberts, personal communication, 29 January 2012).

The Guardians of the NZSF's official response to the story argued that the investment was passive rather than active. NZSF chief executive Adrian Orr (2012) stated: 
We have only very small, passive investments, representing a fraction of a per cent of the near $\$ 18$ billion in the New Zealand Superannuation Fund, in Freeport McMoRan Copper \& Gold and in Rio Tinto plc. Nevertheless, we have over the past five years repeatedly communicated our concerns about the social and environmental issues associated with the operation of Grasberg to company management (p. 20).

But the fact that the NZSF investment is so small led one member of the public to question the validity of the NZFS argument for staying invested in the mine. Metro reader Zara Leggett (2011) replied to the NZSF's response by saying:

Even if you put aside the human rights abuses, which, horrible though they are, can be argued to be outside the jurisdiction of the company itself, the fund acknowledges that there are both environmental and union breaches. These are long-running issues, which have not been rectified or even improved. I appreciate the idea of engaging for change, but at what point do we acknowledge that change is not going to happen? And when do we admit that the NZ\$1.3 million invested is pocket change and therefore divestment is not a credible threat.

The Guardians of the NZSF also went on to again argue against 'walking away' from their investment, saying:

The Guardians engage precisely because we acknowledge that company operations fail our standards. The past five years of engagement has occurred because the Guardians are trying to effect change in company operations sufficient to meet those standards. The article, as do some other outside observers of responsible investment practice, equates responsible investment to exclusion. However a properly considered responsible investment approach should also include a significant element of seeking to change company behaviour as it is that, not walking away, which makes the biggest impact on the people and environments most affected by problematic company behavior.

But this did not satisfy leading investigative journalist Nicky Hager (2012): 'It is a fine piece of journalism,' he wrote.

Freeport is a blight on our region, usually protected from criticism and change simply because it is out of sight and the media in West Papua is 
so strictly controlled. You gave the spokespeople for the Super Fund a generous amount of space to justify why they invest New Zealanders' money in the mine. They failed. Hopefully the fund is now reconsidering its position (p. 20).

It may be that by approaching the research and publication of 'Blood Money' with some peace journalism frames of reference increased public understanding of an issue and region previously ignored by mainstream NZ media. The fact that the author chose to focus her attention more heavily on talking to peacemakers rather than the traditional journalistic approach of focusing on conflict-makers is also noted as a fairly unique way of working with a story.

It could be that giving the NZSF, the mine, the miners, peace workers, human rights groups a fair amount of space to have their views heard and scrutinised, led to a depth of understanding that may have been missed if the story had been approached in a more adversarial manner.

\section{Note}

1. West Papua (also known as Western New Guinea) has been adopted by Pacific Journalism Review to refer collectively to the territory covering the western peninsula of the Pacific island of New Guinea where the issue of Melanesian independence or self-determination is critical. Indonesia has administered the territory as two provinces since 2003-West Papua and Papua. A former colony as part of the Netherlands East Indies, Indonesia attempted to seize control with a seaborne and paratrooper invasion in 1963 with little success. However, it succeeded in incorporating the territory as part of Indonesia in the United Nations mandated so-called 'Act of Free Choice' in 1969 that has been disputed ever since by many Melanesian West Papuans.

\section{References}

Abplanalp, K. (2011, December). Blood money, Metro magazine, Issue 359, pp. 38-44. Aslam, R. (2011). Peace journalism: A paradigm shift in traditional media approach. Pacific Journalism Review, 17(1), pp. 119-139.

Bacon, W. (2006). Journalism as research? Australian Journalism Review, 28(2), pp. 147-157.

Bacon, W. (2011). Investigative journalism in the academy-possibilities for story telling across time and space. Pacific Journalism Review, 17(1), pp. 45-66.

Chesterfield, N. (2011). Free the people? Free the media! Broadcasting Papua's songs of freedom. In P. King, J. Elmslie \& C. Webb-Gannon (Eds.), Comprehending West Papua (p. 32). Centre for Peace and Conflict Studies, University of Sydney. 
Galtung, J. (2003). Peace journalism. Media Asia, 30(3), pp. 177-180

Guardians respond to Metro magazine article on Grasberg mine (2011, November 28). NZ Superannuation Fund website. Retrieved on 1 February 2012, from www. nzsuper.co.nz/news.asp?pageID $=2145831983 \&$ RefId $=2141741231$

Hackett, R. A. (2011). New vistas for peace journalism: Alternative media and communication rights. In Lynch, J., Hackett, R. A., and Shaw, I. S. (Eds.), Expanding peace journalism: Comparative and critical approaches (pp. 35-69). Sydney: Sydney University Press.

Dixit, K. (2011). Real investigative journalism in a virtual world. Pacific Journalism Review, 17(1), pp. 12-19.

Hager, N. (2012, January-February). Upfront-Yours etc, Metro magazine, Issue 360. Hager, N. (2011). Transcript from interview with Karen Abplanalp, March 28.

Hanitzsch, T. (2007). Situating peace journalism studies: A critical appraisal In Conflict \& Communication Online, 6(2).

Leith, D. (2003). The politics of power: Freeport in Suharto's Indonesia. Honolulu: University of Hawaii Press.

Indonesian Human Rights Committee Online. Retrieved 29 January 2012, from http:// indonesiahumanrights.org.nz/

Legget, Z. (2011). Metro Facebook page. Retrieved 29 January 2012, from www. facebook.com/\#!/metroNZ

Mills, C. (2012, January-February). Upfront-Yours etc., Metro magazine, Issue 360. Orr, A. (2012, January-February). Upfront-Yours etc., Metro magazine, Issue 360.

Perrottet, A., and Robie, D. (2011a). Pacific media freedom 2011: A status report. Pacific Journalism Review, 17(2), pp. 148-146. Retrieved on 31 January 2011, from www.pjreview.info/articles/pacific-media-freedom-2011-status-report-513

Perrottet, A., and Robie, D. (2011b). Papua a media black spot, New Matilda. Retrieved on 31 January 2012, from www.newmatilda.com/2011/10/24/papua-media-blackspot

Robie, D. (2011). Conflict reporting in the South Pacific: Why peace journalism has a chance. The Journal of Pacific Studies, 32(2), pp. 221-240.

Workers may return to work (2012, January 1), The Jakarta Post. Retrieved on 27 January 2012, from www.thejakartapost.com/news/2012/01/03/workers-mayreturn-tuesday-freeport.html

Karen Abplanalp is an Auckland-based freelance photographer and writer based at the Pacific Media Centre. She would like to acknowledge Professor David Robie for his support and assistance with this article and with the research for 'Blood Money', an article originally published in Metro magazine. Abplanalp is a postgraduate communication studies student at Auckland University of Technology.

karen@doublescoop.co.nz 


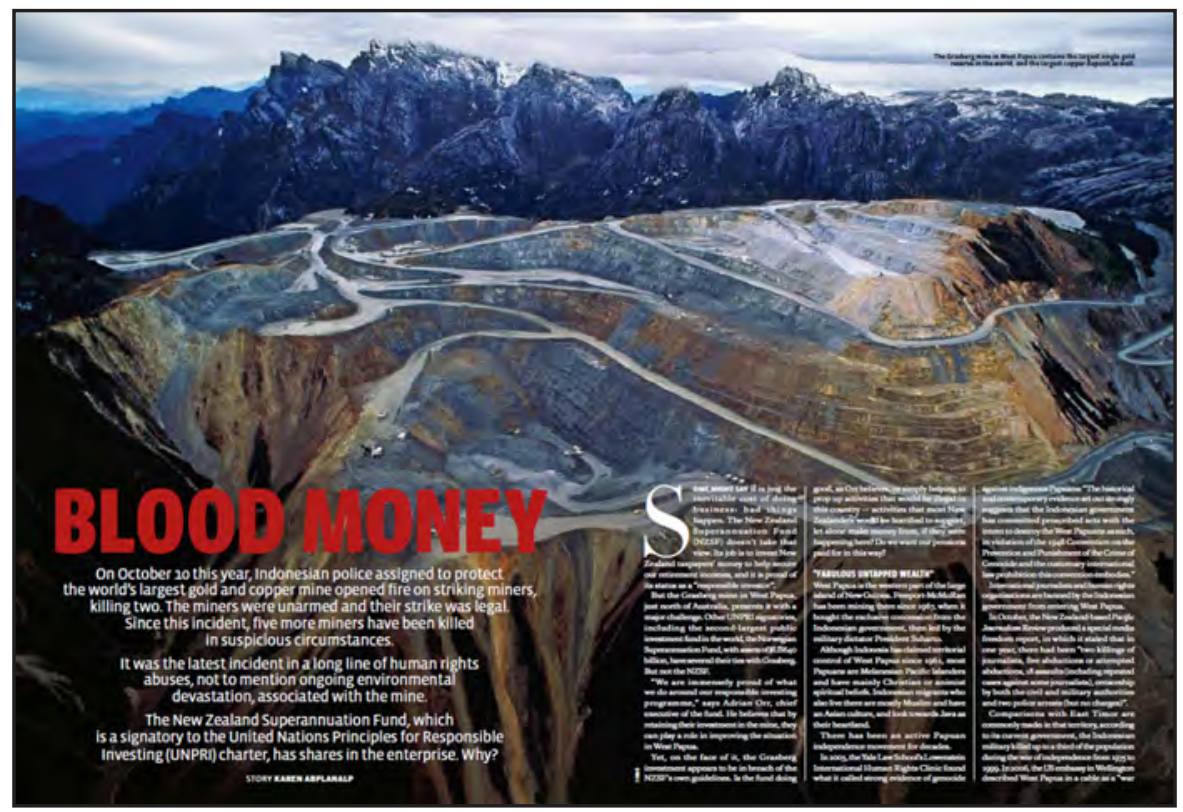

\section{BLOOD MONEY}

First published in Metro magazine in New Zealand.

On October 10 [2011], Indonesian police assigned to protect the world's largest gold and copper mine opened fire on striking miners, killing two. The miners were unarmed and their strike was legal. Since this incident, five more miners have been killed in suspicious circumstances. It was the latest incident in a long line of human rights abuses, not to mention ongoing environmental devastation, associated with the mine. The New Zealand Superannuation Fund, which is a signatory to the United Nations Principles for Responsible Investing (UNPRI) charter, has shares in the enterprise. Why?

\section{STORY: Karen Abplanalp}

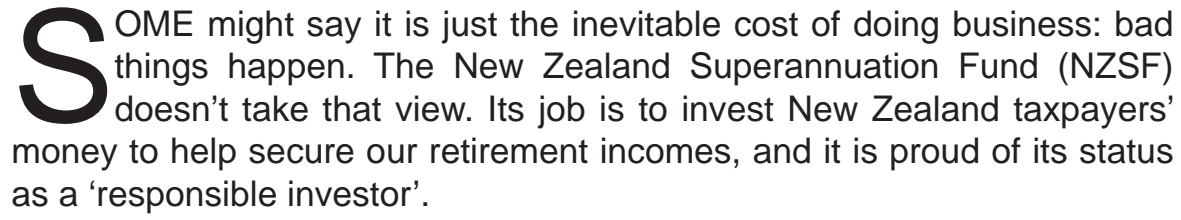


But the Grasberg mine in West Papua, just north of Australia, presents it with a major challenge. Other UNPRI signatories, including the secondlargest public investment fund in the world, the Norwegian Superannuation Fund, with assets of US\$640 billion, have severed their ties with Grasberg. But not the NZSF.

'We are immensely proud of what we do around our responsible investing programme,' says Adrian Orr, chief executive of the fund. He believes that by retaining their investment in the mine, they can play a role in improving the situation in West Papua.

Yet, on the face of it, the Grasberg investment appears to be in breach of the NZSF's own guidelines. Is the fund doing good, as Orr believes, or simply helping to prop up activities that would be illegal in this country-activities that most New Zealanders would be horrified to support, let alone make money from, if they were happening here? Do we want our pensions paid for in this way?

\section{'Fabulous untapped wealth'}

West Papua is the western part of the large island of New Guinea. FreeportMcMoRan has been mining there since 1967, when it bought the exclusive concession from the Indonesian government, then led by the military dictator President Suharto.

Although Indonesia has claimed territorial control of West Papua since 1961, most Papuans are Melanesian Pacific Islanders and have mainly Christian or animist spiritual beliefs. Indonesian migrants who also live there are mostly Muslim and have an Asian culture, and look towards Java as their heartland.

There has been an active Papuan independence movement for decades.

In 2003, the Yale Law School's Lowenstein International Human Rights Clinic found what it called strong evidence of genocide against indigenous Papuans: 'The historical and contemporary evidence set out strongly suggests that the Indonesian government has committed proscribed acts with the intent to destroy the West Papuans as such, in violation of the 1948 Convention on the Prevention and Punishment of the Crime of Genocide and the customary international law prohibition this convention embodies.'

International journalists and human rights organisations are banned by the Indonesian government from entering West Papua.

In October, the New Zealand-based Pacific Journalism Review produced a special media freedom report, in which it stated that in one year, there had been 'two killings of journalists, five abductions or attempted abductions, 
18 assaults (including repeated cases against some journalists), censorship by both the civil and military authorities and two police arrests (but no charges)'.

Comparisons with East Timor are commonly made: in that territory, according to its current government, the Indonesian military killed up to a third of the population during the war of independence from 1975 to 1999. In 2006, the US embassy in Wellington described West Papua in a cable as a 'war zone in many places', noting also: 'It has all the makings of the next East Timor, except that this time Jakarta will not let go.'

The reason? The region has enormous investment potential and 'fabulous untapped wealth'. The cable added that 'the huge Freeport gold and copper mine is the largest taxpayer in Indonesia'. Grasberg's annual tax bill is US\$1.4 billion.

In 2010, the mine produced 5377 ounces of gold and 1651 tons of copper a day. It is owned and operated by a company called PT Freeport Indonesia, a subsidiary of Freeport-McMoRan, a giant American company, and Rio Tinto, the British/Australian conglomerate (which also owns the Bluff aluminium smelter). The Indonesian government retains a 9.4 percent interest.

\section{'Divestment is a form of failure'}

'Responsible investing', as the UN calls it, is big business and growing fast: Adrian Orr says it's hard to keep count of the investors signing up to the UNPRI. The current figure is 900 , and between them they manage assets of up to $\$$ US30 trillion. That is US $\$ 30,000,000,000,000$. In Orr's words, it's 'a lot of dough'.

The NZSF, like many funds, invests on the basis of a global portfolio list which it customises to its own requirements. The UNPRI guidelines provide ethical tests that help with this. The first is legality: whether it is legal for the company to make the things it makes. Orr explains that the fund has no money in cluster bombs, for example, because they are illegal.

A second test is whether engagement with the company might realistically lead to ethical improvements. The fund no longer has money in tobacco companies either, having accepted that in ethical terms there is no such thing as a good cigarette.

A third test relates to our own reputation. 'Legally, we are mandated to have concern for New Zealand's reputation in the global community,' says Orr, 'so we invest to avoid prejudice to New Zealand's reputation.'

Assuming these conditions are met, the UNPRI approach is to 'engage'. In an impure world, the UNPRI doesn't favour just the ethically 'clean' invest- 
ments -it also encourages investments where it's possible to effect positive change. 'Typically,' says Anne-Maree O'Connor, head of responsible investment for the NZSF, 'engagement activity involves making a company aware of relevant international standards and encouraging them to adapt their activities accordingly.'

The NZSF approach has its critics. Green Party leader Russel Norman, who has campaigned on NZSF investments, says: 'In order for engagement to be effective, it needs to carry a credible threat of divestment, which the NZSF has shown time and again it does not have. The divestments they have made in regard to tobacco, cluster munitions and nuclear weapons manufacturers have only come as a result of an enormous amount of public pressure.'

Freeport is important to the NZSF, although not because of the money: it's got less than $\$ 20$ million invested in the mine. There are bigger issues at stake.

Adrian Orr: 'This issue is in what we consider our own backyard, which even though it is a small amount of dough, as a proportion of our fund, we are saying, 'Well, this is the type of thing that we could take a lead on and be engaged directly with this company.'

It's not, says Orr, 'us turning up to Freeport with a wet bus ticket [saying], "Hey, we own 0.001 per cent of your company, you be warned."' Instead, they value the strength in numbers they gain through the UNPRI.

'You have some meaningful big-hitters who you can collaborate with to influence positive change. It's the only way. The alternative is to walk away. Mining is still going to be mining, we don't know what capital will replace our capital, and we don't know what standards that capital will bring with it. Walking away is an admission of "We can't make a difference."'

In other words, he believes a goldmine in the developing world can be a very good option for a relatively small responsible investor like NZSF, because it provides an opportunity to join with others to make the world a better place.

The NZSF has supported a move to have an environmental expert appointed to the board of Freeport McMoRan, but the bid gained only 30 percent support and failed.

Sometimes, Orr acknowledges, walking away can be the right thing to do. 'We see divestment as a form of failure,' he says, 'but at some point, if we are just not getting there with engagement, you may choose to divest. If there is an action that is clearly in breach of what your environmental, social or governance standards are and you are in a situation where you can't get them to change, or you see you are not going to be able to make 
the change, or that it is just illegal outright, then you divest.'

And that's the fourth test: once you've engaged, you need to know you really can make a difference. How does the NZSF do that?

When the fund makes a decision on engagement, it applies its own standards, notably, at Grasberg, relating to human rights, corruption and the environment.

\section{'The hard-core troops of Indonesia'}

NZSF standards on human rights: To support and respect human rights; no complicity in abuses.

In September [2011], around 8000 Grasberg miners went on strike, asking for a pay increase. Although the strike was legal under Indonesian law, Freeport responded on October 10 by bringing in other workers to replace the miners - an act that was illegal under the same law. The miners tried to blockade the mine and that is when the Indonesian paramilitary police, who receive payments from Freeport, opened fire and killed two of the workers.

It is unclear whose orders the troops were following. West Papua is currently in a state of widespread unrest and there have been many other recent instances of paramilitary action against groups of civilians, including, on October 19, an attack on the unarmed third Papuan People's Congress. On that occasion, six people were killed and hundreds more detained. Seventeen people are still missing and presumed dead, and allegations of torture are currently being investigated.

The Yale Law School report in 2003, three years before the NZSF invested in Grasberg, had already documented human rights abuses in the region: 'The Indonesian military and security forces have engaged in widespread violence and extrajudicial killings in West Papua. They have subjected Papuan men and women to acts of torture, disappearance, rape, and sexual violence, thus causing serious bodily and mental harm.' Amnesty International Indonesian researcher Joseph Benedict says, 'The Indonesian military have a history of committing human-rights abuses and should not be involved in providing security for the Grasberg mine.'

Dr Denise Leith, who spent five years researching Freeport's activities for her book The Politics of Power, Freeport in Suharto's Indonesia (Leith, 2003), agrees. She says the relationship between the mine and the state security forces is difficult. Those involved at Grasberg include 'the hard-core battle-trained troops of Indonesia', trained in unconventional warfare and counter-insurgency.

'If Freeport now tried to distance themselves from the Indonesian military, 
or tried to withdraw payments [to] the Indonesian military, I would imagine [the military] would do what they have always done, and they would cause trouble for Freeport, whether it is killing traditional people, or cutting the slurry line... There are many ways they can do it and these are the ways they usually do it.'

So, the problem is not just that Freeport's security forces have been involved in killings, but that it is likely Freeport does not have control of those forces.

I asked Adrian Orr and Anne-Maree O'Connor if the killings changed anything for them. Orr: 'They work in an incredibly volatile area.' O'Connor: 'It shows the situation they work in is really difficult.'

Didn't those killings breach the fund's own standard of legality? O'Connor: 'It is not the company [doing the shooting].'

But doesn't the company pay the police and military for security? Orr: 'The company doesn't have a contract to say, "Go and do this behaviour." The company has a security contract.'

Later, O'Connor provided a further response: 'Because an issue is particularly challenging, and seemingly intractable, is not in itself a reason to avoid engaging with companies. In fact, it may be the very issues that investors should focus more on, within their own resource constraints.'

But, she added, 'We expect Freeport-McMoRan to itself act in compliance with the UN standards and where it is able, to encourage security forces involved in the protection of the mine to act according to UN standards.'

O'Connor says several factors give them hope. One is that Freeport has signed up to the Voluntary Principles on Security and Human Rights (VPSHR). 'The issue of security forces and human rights is a challenging issue particularly for the resources sector and has therefore been the focus of considerable attention from NGOs [non-governmental organisations], companies, investors and government bodies. One outcome has been the VPSHR, which has companies, including Freeport, and NGOs working constructively together.'

Those NGOs are not all as keen on the VPSHR as she is. Patrick Holmes from Amnesty International: 'Voluntary principles on security and human rights are great in terms of providing a platform to guide the operation of companies to the promotion and protection of human rights. However, it is voluntary to sign up to the principles and voluntary to fulfil them. We should be able to hold these companies to account for breaching people's fundamental human rights, [but] the voluntary principles do not provide the legal mechanism to do so.' 
Shell Oil, recently accused by a British Guardian investigation of fuelling human rights abuses by paying 'huge contracts' to Nigerian armed militias, is a VPSHR signatory.

Dr Chris Ballard, who has studied human rights in the mining sector in Indonesia, says, 'For many critics, Freeport's new-found human rights awareness is little more than further evidence of the company's ability to pay lip service to corporate social responsibility and human rights principles.'

Nevertheless, O'Connor insists that the VPSHR and related agreements 'establish a sound basis for companies in high-risk regions to manage the associated environmental, social and governance risks to the companies themselves, to their workers and to the communities where they operate'.

Another cause for NZSF optimism: Freeport has established a 'whistleblowing' system, under which staff can complain to the company about abuses.

In 2009, only two cases were reported. O'Connor: 'Once they got the protection of the whistle blower more enforced, they had more cases coming through.' The next year, there were five complaints.

I asked Frans Okoseray, a member of the PT Freeport Union Board, about this. He said: 'There is a human rights officer in PT Freeport Indonesia, but they are not independent. They are employed by Freeport. We can only ask for assistance from human rights protection agencies outside the company.'

O'Connor is also pleased Freeport provides human rights training to employees.

Okoseray is sceptical about that too: 'Human rights training is often done in Freeport Indonesia, but it is just a formality, there is no real practice in the field.'

The last independent human rights audit on Freeport was in 2007.

\section{'A lonely, horrible existence'}

NZSF standards on corruption and bribery: to be anti-corruption; to work against corruption.

The Freeport contract for security is with the police and includes the use of their paramilitary wing, known as the Mobile Brigade or Brimob. Freeport has also made payments for security to the military.

Denise Leith points out that it is illegal in Indonesia 'for people of a foreign country, as it would be in any country, to pay money to its police or military, and it is illegal under US law for US citizens to be paying money to the police or military of another country'. 
It's possible Freeport doesn't choose to hire state forces for security, but that its hand is forced by the government. Leith: 'I believe Freeport would dearly love the Indonesian military to go. They cause them a huge amount of trouble and cost them a huge amount of money. But they won't go, because to be posted around the Freeport concession is a very, very lucrative position.'

The region is rife with illegal activity, including stealing from the company, illegal gold panning in the tailings, prostitution, drugs and the export of exotic animals. Leith says military and police personnel are heavily involved in all this, and the company cannot complain because there is no one to complain to.

'It is a lonely, horrible existence there. The Indonesian military personnel have this mind-set that Freeport owes them, and Freeport needs to pay them.'

To make matters worse, Brimob and the military are engaged in a turf war over who will control the illegal activity, and that drives a lot of the violence.

Joseph Benedict from Amnesty International adds that there are allegations that military and police create security incidents in order to secure payments, and that this further compromises the safety of the people of West Papua. 'The Indonesian military act with impunity,' he says.

Freeport has recently come under Indonesian media pressure for illegal payments, forcing the police to admit receiving 'lunch money' of \$US14 million a year from the company. Freeport has responded with a statement that the funds are legal under the Voluntary Principles on Security and Human Rights.

Given that legality is a core issue for the NZSF, I asked Orr to comment on Freeport's payments to the Indonesian military, which, despite the company's claim, appear to breach Indonesian and American law and would not be legal here either.

On Orr's behalf, the fund's head of PR, Paul Gregory, provided a circuitous response: 'The "is it legal in New Zealand?"' test is one we apply when we are considering excluding or divesting a company from the fund. That decision is based on what the company does-its product or service. Freeport's service is mining, which is clearly legal in New Zealand.

'Our view of what good practice is for any given company is driven by international standards relevant to the company's activity. What is legal or otherwise in New Zealand, or any other country, is of limited use when considering good practice. Not least because practices vary between countries.'

O'Connor noted that Freeport now records payments to the state forces in its annual reports. She says this is another improvement in the company's practices. 


\section{'This process is irreversible'}

NZSF standards on the environment: A precautionary approach; act to promote greater responsibility; encourage environmentally friendly technologies.

The Yale Law School report linked environmental destruction and its effects on West Papuan people: 'Systematic resource exploitation, the destruction of Papuan resources and crops, compulsory (and often uncompensated) labour, transmigration schemes and forced relocation have caused pervasive environmental harm to the region, undermined traditional subsistence practices and led to widespread disease, malnutrition and death among West Papuans.'

Dealing with waste is just one of the environmental issues confronting the mine. Freeport uses 'riverine disposal': 230,000 tonnes of tailings, much of it toxic, is discharged into a natural river system every day. This practice is not accepted internationally, and according to the Norwegian Superannuation Fund, Indonesia and Papua New Guinea are the only countries that still allow it.

The Norwegian fund found that 'waste rock overburden is forecast to reach three billion tonnes during the mine's lifecycle. This waste rock results in the generation of acid water containing heavy metals, which may lead to considerable pollution of groundwater and water systems. Once this process has been initiated, it is irreversible and may go on for centuries.'

O'Connor says they have made gains. 'This raised an issue for us-if copper is the most toxic to aquatic life, then the company should publish copper levels in its effluent in its main public reporting. In the 2008 report, they report effluent indicators for Europe and North America but not Indonesia. We then raised the issue with the company. If you then look at Freeport's 2009 report, they included Indonesia. A partial but not full step toward what we raised with them.'

O'Connor notes that Freeport is now a signatory to the ISO 1400 environmental standard, but whether it meets the standard (to be decided in 2012) will be largely based on its own internal assessment. 'Reputable third-party audits are not required.'

Actually, that's true for most things at Grasberg. 'It is good practice if a company gets their reports independently audited or verified,' says O'Connor, 'but it is not the role of a shareholder like us, who have very small holdings in that company, and it is impossible in fact for us to get verification of their report.'

She says we should remember Freeport is working under Indonesian 
environmental standards, and Orr adds that 'what is legal in Indonesia may not be legal here'.

The Norwegian Superannuation Fund considered this view, and noted: 'Lenient legislation in a country does not automatically justify a heavy environmental burden if the damage is considerable.'

It was environmental damage that spurred the Norwegians, after years of investigation, to divest from both of Grasberg's principal owners, Freeport in 2006 and Rio Tinto in 2008. Announcing the latter decision, the Norwegian Finance Minister, Kristin Halvorsen, said: 'Exclusion of a company from the fund reflects our unwillingness to run an unacceptable risk of contributing to grossly unethical conduct. The [Norwegian] Council on Ethics has concluded that Rio Tinto is directly involved, through its participation in the Grasberg mine in Indonesia, in the severe environmental damage caused by that mining operation. There are no indications ... the company's practices will be changed in future.'

I asked why the New Zealand Fund did not pull out when the Norwegians did. O'Connor replied that different ethical principles and laws apply to New Zealand from those in Norway.

\section{'A nice set of high-level principles'}

Less than $\$ 20$ million: why do they bother? Because there are bigger issues at stake.

On November 15 this year, the New Zealand Trade Minister, Tim Groser, and his Australian counterpart, Craig Emerson, welcomed a new member to the Asean-Australia-New Zealand Free Trade Area: Indonesia.

Groser called Indonesia 'one of our most important trading partners' and Emerson said, 'Indonesia's importance to Australia and New Zealand will only grow.'

Does that help explain the reluctance of the NZSF to divest from Grasberg? Right through the 24 years of East Timor's struggle for independence, the New Zealand government was loath to criticise Indonesia, even when New Zealanders were known to have been murdered by Indonesian troops. Is the same thing happening here?

Not according to Adrian Orr: 'It is important that you separate matters of government-nation states, laws, trade, etc-and our operation within those laws... We do not make laws, or trade negotiations, or anything else. We are simply an investment institution operating with the highest integrity within current laws and abiding by international UNPRI standards.'

Not to mention New Zealand law. As Orr mentioned earlier, he and the 
other Guardians of the Fund are required (under the New Zealand Superannuation and Retirement Income Act) to manage the funds in a way that 'avoids prejudice to New Zealand's reputation as a responsible member of the world community'.

I asked Prime Minister John Key if he thought the Grasberg investment could damage that reputation. He replied: 'NZ Super Fund investment decisions are matters for the Guardians of the Fund. I believe ethical or responsible investment policies are important for organisations like the NZSF, and I am advised that their approach is regarded as best practice.'

Best practice? Orr: 'The United Nations' Principles for Responsible Investment give us this nice set of high-level principles that we can say globally, these are agreed global best practices.'

Dr Robert Howell, chair of the Council for Socially Responsible Investing, says that's meaningless. 'The problem with the UNPRI is that you can be signed up for this, and yet still be invested in a whole variety of companies that I would consider to be unethical, and yet you get the tick from the UNPRI... It doesn't actually mean anything.'

The NZSF's stake in Grasberg is a touchy subject. Several leading investment experts, including commentators and responsible-investment experts, told me they were 'unable to assist with inquiries about the Super Fund and Freeport-McMoRan and Rio Tinto', or were simply unwilling to speak publicly.

The fund, they said, was simply too large and the investment community here too small: 'No one will go on the record,' said one fund manager, 'because they all want the Super Fund's business.'

Even some NGOs were unwilling to comment publicly.

\section{'This is just too hard'}

Adrian Orr doesn't argue that the mine is run well, from an ethical standpoint, and has no real answer to the charges that it fails the NZSF's own standards on human rights, corruption and environmental harm. But he values our status as a Pacific nation and he believes in engagement.

And yes, there has been progress. But it is only in the sense that more things are being reported-which, in the absence of independent auditing, is not at all the same thing as transparency. The NZSF has not been able to point to practical gains.

I talked to Brother Budi Hernawan, a Franciscan friar who has lived in West Papua for 14 years and whose friary was attacked on October 19 by security forces hunting for members of the Papuan People's Congress who had escaped the shootings earlier in the day. 
'I don't see any significant progress on human rights compliance by Freeport. Violence and death remain a puzzle for many people. Let alone the environmental degradation and social destruction resulting from the dynamics of a mining town.' That sounds like an argument for divestment.

But, when I asked if him if he thought the NZSF should pull out of Grasberg, he replied: 'Many West Papuans around Freeport mine called on the company to leave a long time ago. But nobody listened to them... If New Zealand can persuade Rio Tinto to pull out, that might have a bigger impact on Freeport.'

Which sounds more like an argument for engagement. Except that investing in Grasberg in order to persuade its owners to pull out or close the mine is not on the agenda of the NZSF.

Orr: 'At some point, if there is a clear breach and you are not getting the changes needed, over a period that you think is meaningful, then of course eventually you have to say, "We're out, this is just too hard."'

Not there yet, apparently. 